\title{
In vitro bone sialoprotein-I expression in combined gingival stromal cells and platelet rich fibrin during osteogenic differentiation
}

\author{
Alexander Patera Nugraha1, Ida Bagus Narmada², Diah Savitri Ernawati ${ }^{4}$, \\ Aristika Dinaryanti ${ }^{3}$, Eryk Hendrianto ${ }^{3}$, Igo Syaiful Ihsan ${ }^{3}$, Wibi Riawan ${ }^{5}$, Fedik \\ Abdul Rantam ${ }^{3,5 *}$ \\ ${ }^{1}$ Doctoral Student of Medical Science, Faculty of Medicine, Universitas Airlangga ${ }^{2}$ Orthodontic Department, ${ }^{3}$ Stem Cell \\ Research and Development Center, Universitas Airlangga, Surabaya, ${ }^{4}$ Oral Medicine Department, Faculty of Dental Medicine, \\ ${ }^{4}$ Biochemistry Biomolecular Laboratory, Faculty of Medicine, Universitas Brawijaya. ${ }^{5}$ Virology and Immunology Laboratory, \\ Microbiology Department, Faculty of Veterinary Medicine, Universitas Airlangga, Surabaya, Indonesia
}

*For correspondence: Email: fedik-a-r@fkh.unair.ac.id; Tel: +625031-5992785 ext 5993016

\begin{abstract}
Purpose: To analyze the expression of bone sialoprotein - I (BSP - I) after the addition of platelet rich fibrin (PRF) in gingival somatic cell (GSC) culture medium during osteogenic differentiation in vitro.

Methods: GSCs were extracted from healthy, 1-month-old, male Wistar rats (Rattus Novergicus), weighing $250-300 \mathrm{~g}$, and which had been randomly selected $(n=4)$. These cells were cultured for 14 days and passaged every 4 days. Five subcultures of GSCs were cultured in three plates (M24) ( $N=$ 54; $n=6$ ) for 7, 14 and 21 days in three preconditioned culture media (group I: plain culture media; group II: preconditioned osteogenic culture media, and group III: preconditioned osteogenic culture media with platelet rich fibrin). The expression of BSP-I was immunocytochemically (ICC) examined with monoclonal antibodies. Homogeneity and normality tests $(p>0.05)$ were then performed followed by an analysis of variance (ANOVA, $p<0.05$ ).

Results: The highest expression of BSP-I was found in group III (Day 21, $13.00 \pm 2.000$ ), while the lowest expression of BSP-I was found in group I (Day 7, $7.33 \pm 1.155)$. There were significant differences between the groups $(p=0.000, p<0.05)$.

Conclusion: PRF stimulates and significantly enhances the expression of BSP-I in GSC culture during osteogenic differentiation. Thus, PRF can be used to accelerate regeneration of alveolar bone defects.
\end{abstract}

Keywords: Alveolar bone, Bone Sialoprotein-I, Gingival Somatic cells, Osteogenic ability, Platelet rich fibrin

\begin{abstract}
This is an Open Access article that uses a funding model which does not charge readers or their institutions for access and distributed under the terms of the Creative Commons Attribution License (http://creativecommons.org/licenses/by/4.0) and the Budapest Open Access Initiative (http://www.budapestopenaccessinitiative.org/read), which permit unrestricted use, distribution, and reproduction in any medium, provided the original work is properly credited.

Tropical Journal of Pharmaceutical Research is indexed by Science Citation Index (SciSearch), Scopus, International Pharmaceutical Abstract, Chemical Abstracts, Embase, Index Copernicus, EBSCO, African Index Medicus, JournalSeek, Journal Citation Reports/Science Edition, Directory of Open Access Journals (DOAJ), African Journal Online, Bioline International, Open-J-Gate and Pharmacy Abstracts
\end{abstract}

\section{INTRODUCTION}

Gingivitis and periodontitis represent the most common diseases affecting the oral cavity.
Severe periodontitis constitutes the sixth most prevalent disease $(11.2 \%)$ with around 743 million people affected worldwide and experienced annual increases between 1990 and 
2010 of $57.3 \%$ [1,2]. Periodontal disease constitutes the second most prevalent dental health problem in Indonesia after caries and malocclusion. In 2013, Basic National Health Research Department (RISKESDAS) reported the prevalence of periodontal disease as having reached $96.58 \%$, thereby representing the second most common oral and dental condition in Indonesia [2-4]. Numerous previous studies relating to dentistry have analyzed the relationship between bacterial activity and inflammation resulting from periodontal disease which lead to problematic alveolar bone defects [5]. To overcome these defects, numerous techniques such as hydroxyapatite $[6,7]$ or Carbonate-apatite bone graft [8] have been developed to stimulate and enhance the regeneration of alveolar bone.

At the time of writing, increasing attention is being paid to biomaterial and cell material interaction [9]. Consequently, it was proposed to combine Gingival Stromal Progenitor Cells (GSCs) and Platelet Rich Fibrin (PRF) in order to stimulate and increase the regeneration of alveolar bone defect. By developing a combination of GSCs and PRF, it is possible to achieve the complete regeneration of alveolar bone defect $[7,8]$. GSCs osteogenic differentiation can be detected by Bone Sialoprotein-I (BSP-I) in its later stages [9-11]. However, information about the effect of the addition of PRF on the expression of BSP-I in GSC culture medium during osteogenic differentiation in vitro remains limited. The main aim of this study was to analyze the expression of BSP-I after the addition of PRF to GSC culture medium during osteogenic differentiation in vitro.

\section{Ethical clearance}

This experimental study was approved by the Department of Dental Medicine, Airlangga University (approval no. 289/HRECC.FODM/

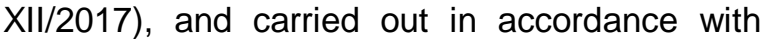
International Guidelines on Animal Model Study for Scientific Laboratory use [12].

\section{Research design}

The study was analytic and true experimental in nature with post-test only control group design. A simple random sampling method and a HosmerLemeshow's sample size formula were used to determine the sample. GSC was extracted from the mandible free gingiva of four male, onemonth-old Wistar rats weighing between 250 and 300 grams. Before the gingivectomy was performed, all the animals were euthanized with anesthesia (ketamine and xylazine $60 \mathrm{mg} / \mathrm{body}$ weight). The extracted GSCs were frequently sub-cultured for 3-5 days in accordance with Nugraha et al recommendations regarding SPCs isolation and culture method [13]. The GSCs (passage 3 - 5) were expanded in three 24-well culture plate ( $N=56$; six samples in each group) for 7,14 and 21 days in three different culture media.

\section{Platelet-rich fibrin extraction}

Wistar strain rats were sacrificed using rodent anesthesia (60 mg /BW) in order to obtain PRF. The blood of these subjects was aspirated and extracted through their hearts. About 3-6 $\mathrm{ml}$ of blood was extracted with a $10 \mathrm{ml}$ syringe before being placed in a plain blood tube and swing centrifuged at 3,000 $\mathrm{rpm} / \mathrm{min}$ for ten minutes) (Thermofisher, US). The PRF was then placed in a M24 culture plate of the treatment group $[7,14]$.

\section{Osteogenic differentiation ability of GSCs combined with PRF}

There were three groups used in this study consisting of group I: GSC cultured in a-Modified Eagle Medium (aMEM) only; group II: GSC cultured in preconditioning osteogenic culture media $(100 \mu \mathrm{g} / \mathrm{ml}$ sodium pyruvate, $0.2 \mathrm{mM}$ ascorbic acid - 2 phosphate, dexamethasone 10 -7 M, 2 mM Lx -glutamine) (Sigma Aldrich, US) and group III: GSC combined with PRF cultured in preconditioning osteogenic culture media. All GSC culture media were changed every 3-4 days. The capacity for GSC osteogenic differentiation was examined on days 7, 14 and 21 [8].

The expression of BSP-I was examined by means of immunocytochemical staining using BSP-I monoclonal antibodies (cat. Sc - 21742) (Santa Cruz Biotechnology, US), a 3.3' diaminobenzidine (DAB) staining kit (Sigma Aldrich, US) and BSP-I monoclonal antibodies (cat. Sc - 21742) (Santa Cruz Biotechnology, US). The expression of BSP-I in all groups was analyzed using an electron microscope $(\mathrm{H} 500 \mathrm{~L}$, Nikon Tokyo, Japan) at 200x magnification.

\section{Statistical analysis}

Data were analyzed by homogeneity and normality tests $(p>0.05)$ and subsequently with analysis of variance (ANOVA) $(p<0.05)$.

\section{RESULTS}

The expression of BSP-I was positive (brown color) in cultured GSC (Figure 1). Normal homogeneously distributed $(p>0.05)$ data was 
obtained. In this study, the highest mean of BSPI expression found in the Day 21 group III, while reduced BS- I expression was found in the Day 7 group I. BSP-I expression was found to be significantly different between the groups $(p<$ 0.05 , Table 1).

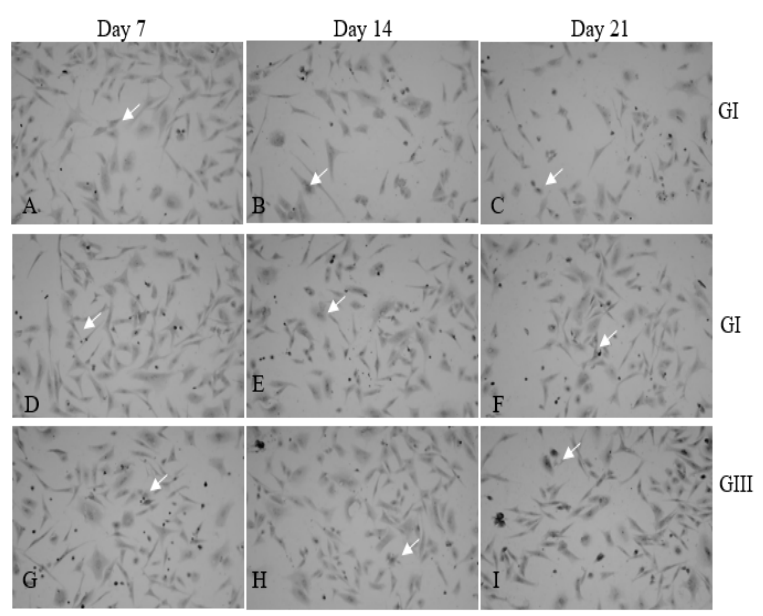

Figure 1: The positive expression of BSP-I (brown color) in the GSC (white arrow). BSP-I expression Group I (A, B, C); Group II (D, E, F); Group III (G, H, I) on Days 7, 14 and 21 (H500L, Nikon Tokyo, Japan) at 200x magnification. Note: Gl = Group 1, Gll = Group II, and GIII = Group III

Table 1: Data for the expression of BSP-I

\begin{tabular}{lccc}
\hline Time & Group I & Group II & Group III \\
\hline Day 7 & $7.33 \pm 1.155$ & $7.67 \pm 1.528$ & $11.33 \pm 1.155$ \\
\hline Day 14 & $8.67 \pm 1.528$ & $9.67 \pm 3.215$ & $11.67 \pm 1.528$ \\
\hline Day 21 & $9.00 \pm 2.000$ & $11.67 \pm 1.528$ & $13.00 \pm 2.000$ \\
\hline${ }^{*} p<0.05$ (one-way ANOVA) &
\end{tabular}

\section{DISCUSSION}

The highest BSP-I expression occurred in group III (Day 21). There were significantly contrasts across all groups $(p<0.05)$. The expression of BSP-I increased gradually from Day 2 to Day 7. These results were in line with those of $\mathrm{Li}$ et al and Tu et al. which posited that BSP-I expression constituted a late stage osteogenic differentiation marker $[15,16]$. The addition of PRF to GSC culture medium during osteogenic differentiation can stimulate BSP-I expression, a position adopted in the study by Duan et al that showed significantly increased BSP-I or Osteopontin expression in combined human GSC and PRF on Day 21 [10].

PRF contained rich and various growth factors such as Thrombospondin-1 which support cytokine migration, while facilitating and stimulating the osteogenic differentiation ability of GSPC. PRF enhances GPCC proliferation, differentiation and migration and the induction of bone formation by increasing BSP-I $[17,18]$.

BSP-I is a glycoprotein most recently detected in osteoblast in 1986. Bone Sialoprotein is a multifunctional protein strongly expressed in bone that acts as a junction protein [19] only found at the intracellular level. BSP-I is a dynamic cytoskeleton regulator and gene expression. Extracellular BSP-I function interacts with certain surface cell receptors. The increased expression of BSP-I is involved in many processes such as alveolar bone remodeling and wound healing $[20,21]$.

BSP-I is strongly expressed in inflammatory conditions in the Extracellular Matrix areas of mineralized tissue such as bone. BSP-I in bone tissue regulates cell-to-cell, cell-to- cell matrix interactions and cartilage-to-cell transition to produce compact bone in the repair process of fractures in osteoclast adhesion in bone matrix. miRNA regulates the secretion and expression of BSP-I such as miR181a / b / c / d. BSP-I is strongly expressed in the later stages of osteogenesis from Day 14 to Day 28 and widely secreted by SPCs that regulate osteogenic differentiation ability $[16,22,23]$.

BSP-I plays an important role in bone remodeling, acting as an osteoclast regulator in the bone mineral matrix to maintain inorganic components of bone such as hydroxyapatite, $\mathrm{Ca}(\mathrm{PO} 4)(\mathrm{OH}) 2$. Decreased expression of BSP-I will cause osteoporosis. BSP-I is also expressed in osteoclasts and osteoblasts responsible for bone remodeling in bone homeostasis $[19,22,24]$.

\section{CONCLUSION}

GSCs cultured in PRF significantly increase BSP-I expression on Day 21. PRF increases and stimulates GSCs osteogenic differentiation ability as measured by BSP-I expression. Further research is required to analyze BSP-I expression during osteogenic differentiation of combined GSCs and PRF in vivo.

\section{DECLARATIONS}

\section{Acknowledgement}

The authors would like to thank the Postgraduate School, Faculty of Dental Medicine, Faculty of Medicine, Stem Cell Research and Development Centre, Universitas Airlangga (UNAIR), Surabaya, East Java, Indonesia for supporting their research. The research grant was provided 
by Program Menuju Doktor Sarjana Unggul (PMDSU) Batch III of the Ministry of Research, Technology and Higher Education, Republic of Indonesia (Kemenristekdikti RI) 2018 with a Letter of Appointment Agreement no. 1035/D3/PG/2017 and Number 2146/D3/PG/ 2017.

\section{Conflict of interest}

No conflict of interest is associated with this work.

\section{Contribution of authors}

The authors declare that this work was undertaken by the individual(s) named in this article who will bear all liabilities pertaining to claims relating to its contents. All the authors made substantial contributions to this study and/or manuscript and approved the final draft of the paper prior to its submission.

\section{REFERENCES}

1. Wang TZ, Fang $\mathrm{CH}$, Hsiao $\mathrm{KJ}$, Chou C. Effect of a comprehensive plan for periodontal disease care on oral health - related quality of life in patients with periodontal disease in Taiwan. Medicine 2018; 97(5): e9749.

2. Kassebaum NJ, Bernabé E, Dahiya M, Bhandari B, Murray CJL, Marcenes W. Global Burden of Severe Periodontitis in 1990 - 2010 A Systematic Review and Meta-regression. J Dent Res 2014; 93(11): 1045-1053.

3. Soeroso $Y$, Akase $T$, Sunarto $H$, Kemal $Y$, Salim $R$, Octavia M, Viandita A, Setiawan J, Bachtiar BM. The risk reduction of recurrent periodontal pathogens of local application minocycline $\mathrm{HCl} 2 \%$ gel, used as an adjunct to scaling and root planing for chronic periodontitis treatment. Ther Clin Risk Manag 2017; 13: 307-314.

4. Ministry of Health and National Institute of Health Research and Development. National report on basic health research, (RISKESDAS) and additional analysis. 3rd ed. Indonesia: Ministry of Health, Republic of Indonesia, Jakarta; 2014: pp 50-55.

5. Henderson B, and Kaiser F. Bacterial modulators of bone remodeling in the periodontal pocket. Periodontol 2018; 76(1): 97-108.

6. Ari MDA, Yuliati A, Rahayu RP, Saraswati $D$. The Differences Scaffold Composition in Pore Size and Hydrophobicity Properties as Bone Regeneration Biomaterial: Experimental article. J Int Dent Med Res 2018; 11(1): 318-322.

7. Rahmawati D, Roestamadji RI, Yuliati A, Bramantoro $T$. Osteogenic ability of combined hematopoetic stem cell, hydroxyapatite graft and platelet rich fibrin on rats (Rattus novergicus). JKIMSU 2017; 6(4): 88-95.
8. Kamadjaja MJK, Salim S and Rantam FA. Osteogenic Potential Differentiation of Human Amnion Mesenchymal Stem Cell with Chitosan-Carbonate Apatite. Bali Med J 2016; 5: 71-77.

9. Cruz-Maya I, Guarino V, Alvarez-Perez MA. Protein based devices for oral tissue repair and regeneration. AIMS Materials Science 2018; 5(2): 156-170.

10. Duan X, Lin Z, Lin X, Wang Z, Wu Y, Ji M, Lu W, Wang $X$, Zhang $D$. Study of platelet-rich fibrin combined with rat periodontal ligament stem cells in periodontal tissue regeneration. J Cell Mol Med 2018; 22(2): 1047-1055.

11. Bouet $G$, Bouleftour W, Juignet L, Linossier MT, Thomas $M$, Vanden-Bossche A, Aubin JE, Vico L, Marchat $D$, Malaval L. The Impairment of Osteogenesis in Bone Sialoprotein (BSP) Knockout Calvaria Cell Cultures Is Cell Density Dependent. PLoS One 2015; 10(2): e0117402.

12. Tan B. Guidelines on the care and use of animals for scientific purposes. National Advisory Committee for Laboratory Animal Research, 2004.

13. Nugraha AP, Narmada IB, Ernawati DS, Widodo ADW, Lestari P, Rantam, FA. Gingival Mesenchymal Stem Cells from Wistar Rat's Gingiva (Rattus Novergicus) Isolation and Characterization (In Vitro Study). J Int Med Res 2018; 11: 694-699.

14. Sumarta NPM, Rantam FA, Hendrianto E, Karsari D, Pramono C. Chondrogenic Differentiation Capacity of Human Umbilical Cord Mesenchymal Stem Cells with Platelet Rich Fibrin Scaffold in Cartilage Regeneration (In Vitro Study). Bali Med J 2016; 5(3): 65-70.

15. Li Q, Reed AD, Min L, Gopinathan G, Li S, Dangaria SJ, Li L, Geng Y, Galang MT, Gajendrareddy P, Zhou Y, Luan X, Diekwisch TGH. Lyophilized Platelet-Rich Fibrin (PRF) Promotes Craniofacial Bone Regeneration through Runx2. Int J Mol Sci 2014;15(5):8509-8525.

16. Tu M, Li Y, Zeng C, Deng Z, Gao S, Xiao W, Luo W, Jiang $W$, Li L, Lei G. MicroRNA-127-5p regulates osteopontin expression and osteopontin-mediated proliferation of human chondrocytes. Scientific Report 2016; 6: 25032.

17. Li Q, Pan S, Dangaria SJ, Gopinathan G, Kolokythas A, Chu S, Geng Y, Zhou Y, Luan X. Platelet-Rich Fibrin Promotes Periodontal Regeneration and Enhances Alveolar Bone Augmentation. Bio Med Res Int 2013; 638043: 1-13.

18. Kobayashi E, Flückiger L, Fujioka-Kobayashi M, Sawada $K$, Sculean $A$, Schaller $B$, Miron RJ. Comparative release of growth factors from $P R P, P R F$, and advanced-PRF, Clinical Oral Investigations, 2016; 20(9): 2353-2360.

19. Sase SP, Ganu JV, Nagane N. Osteopontin: A Novel Protein Molecule A Review. Indian Med Gaz 2012(2): 62-66.

20. Uede T. Osteopontin, intrinsic tissue regulator of intractable inflammatory diseases. Pathol Int 2011; 61: 265-280.

21. Bandopadhyay M, Bulbule A, Butti R, Chakraborty G, Ghorpade P, Ghosh P, Osteopontin as a therapeutic

Trop J Pharm Res, December 2018; 17(12): 2344 
target for cancer. Expert Opin Ther Targets 2014; 18: 883-895.

22. Chen $Q$, Shou $P$, Zhang $L, X u C$, Zheng $C$, Han $Y$, Li W, Huang $Y$, Zhang $X$, Shao $C$, Roberts $A$, Rabson $A B$, Ren $G$, Zhang $Y$, Wang $Y$, Denhardt $D T$, Shi $Y$. An osteopontin-integrin interaction plays a critical role in directing adipogenesis and osteogenesis by mesenchymal stem cells. Stem Cells 2014; 32(2): 327337.

23. Nugraha $A P$, Narmada IB, Ernawati $D S$, Dinaryanti $A$, Hendrianto E, Riawan W, Rantam FA. Bone Alkaline
Phosphatase and Osteocalcin Expression of Rat's Gingival Mesenchymal Stem Cells Cultured in Platelet-Rich Fibrin for Bone Remodeling (in vitro study). Eur J Dent 2018; 12: 566-573.

24. Nugraha AP, Narmada IB, Ernawati DS, Dinaryanti A, Hendrianto E, Ihsan IS, Rantam FA. Osteogenic Potential of Gingival Stromal Progenitor Cells Cultured In Platelet Rich Fibrin Is Predicted By Core-Binding Factor Subunit-A1/Sox9 Expression Ratio (In vitro). Research 2018; 7: 1134. 